\title{
Model Persamaan Struktural Kualitas dan Biaya Jasa Terhadap Kepuasan dan Loyalitas Mahasiswa
}

\author{
Hisyam Ihsan \\ Pasca Sarjana Universitas Negeri Makassar, e-mail: hisyamihsan@gmail.com
}

\begin{abstract}
Abstrak: Penelitian ini bertujuan untuk mengembangkan dan memverifikasi model hubungan antara berbagai faktor yang terkait dengan kepuasan dan loyalitas mahasiswa, termasuk kedudukannya sebagai mitra partisipan efektif dari pendidikannya sendiri, sekaligus melihat dampak sikap dan persepsinya pada tataran hasil (outcome) dalam institusi pendidikan tinggi. Hubungan kualitas jasa pendidikan dan biaya jasa yang dialami dengan kepuasan dan loyalitas mahasiswa diuji secara empirik dengan menggunakan Model Persamaan Struktural (Structural Equation Modeling atau SEM). Hasil penelitian memberikan dukungan terhadap usulan model aplikatif yang menggambarkan sikap dan perilaku mahasiswa baik sebagai konsumen maupun mitra-partisipan terhadap layanan jasa pendidikan tinggi dalam memprediksi kepuasan dan loyalitas mahasiswa. Melalui model tersebut dapat disimpulkan bahwa makin berkualitas layanan jasa yang diberikan kepada mahasiswa menurut persepsi dan keterlibatannya akan semakin puas dan loyal mahasiswa tersebut dalam penyelenggaraan pendidikan; atau ekuivalen bahwa makin positif sikap dan perilaku mahasiswa terhadap penyelenggaraan pendidikan, akan semakin puas dan loyal mahasiswa tersebut, dan tentu saja berakibat akan semakin baik kinerja pendidikan tinggi ke depan dalam perspektif jangka panjang.
\end{abstract}

Kata kunci: kualitas jasa pendidikan, biaya jasa yang dialami, kepuasan, loyalitas, mitra-partisipan, Structural equation modelling

\begin{abstract}
The objective of the study accordingly is to develop and verify the relationships model among various factors related to students' satisfaction and loyalty and their status as effective participating partners of their educational institutions (Partnert-Participant), as well as the impact of these students' attitudes and perceptions on the outcomes level of undergraduate program in a higher education. The relationship between the perceived quality of educational service as well as the price and the students' satisfaction and loyalty are empirically tested using Structural Equation Modeling (SEM). The result of the study supports the proposed applicative model which describes the attitudes and perception of the students both as consumers and as co-producer of the educational services in relation to their satisfaction and loyalty. The model concludes that the more positive the attitudes and the perceptions of the students to the educational process, the more satisfied and loyal the students will be, the better performance of higher education as the outcome in a long time perspective.
\end{abstract}

Key words: Educational service quality. Perceived price, satisfaction, loyalty, Partnert-Participant, and structural equation modelling

\section{Pendahuluan}

Pertumbuhan ekonomi dan kemakmuran suatu negara bergantung pada sumber dayanya. Di antara semua sumber daya tersebut, kemampuan manusia (manpower) telah memainkan peranan yang krusial dan sangat penting dalam menjalankan ekonomi. Tidak dapat dipungkiri bahwa manusia-manusia terpelajarlah yang berperan di dunia sekarang ini. Orang-orang terpelajar tersebut di negara mana pun adalah hasil dari proses pendidikan.

Berbagai upaya telah dilakukan dalam upaya pembaharuan pendidikan, dalam era reformasi ini, pemerintah Indonesia sudah memberikan prioritas pada sektor pendidikan. Pada jenjang pendidikan tinggi salah satu upaya tersebut diwujudkan melalui UU Nomor 20 Tahun 2003 tentang sistem pendidikan nasional yang menetapkan bahwa 
Perguruan Tinggi merupakan badan hukum. Ini berarti pemerintah telah memberikan otonomi dan akuntabilitas terhadap Perguruan Tinggi untuk dikelola secara profesional.

Namun, hingga kini masih banyak keluhan dari berbagai pihak tentang kompetensi lulusan berbagai jenis dan jenjang pendidikan. Keluhan tentang rendahnya kompetensi lulusan Perguruan Tinggi di Indonesia sudah menjadi sorotan pada dunia pendidikan dewasa ini.

Jika dipandang dari perspektif pasar, dapat dinyatakan bahwa produksi jasa yang pendidikan tinggi tampilkan belum bisa memenuhi kebutuhan konsumennya. Menurut, Dirks, (1998), proses di mana produser mempersiapkan suatu penawaran dan interaksi dengan konsumen dikenal sebagai pemasaran, dan merupakan gambaran tubuh teori pemasaran (a body of marketing theory).

Dalam manajemen pemasaran telah berkembang konsep bahwa pengelolaan lembaga perlu disesuaikan dengan tuntutan pelanggannya, tidak terkecuali perguruan tinggi dalam memberikan pelayanan jasa. Pelanggan akan menuntut kepuasan terhadap produk yang dibelanjakan dari lembaga tersebut. Terlebih dalam pasar global, tidak ada satupun bisnis yang bisa bertahan lama tanpa adanya pelanggan yang puas dan loyal (Fandy, 2005: 344). Hal ini terkait dengan konsep pemasaran strategis, di mana salah satu strategi yang paling populer adalah relationship marketing (RM). Sejalan dengan itu, Forbes \& Linda (2004) membangun pasar siswa internasional melalui solusi Educational-Balanced Scorecard di Australia agar diperoleh jaminan dari berbagai perspektif ukuran kinerja lembaga pendidikan dalam memenuhi tuntutan pelanggan.

Dalam literatur pemasaran pendidikan tinggi belum banyak mengungkap sejauh mana kualitas produk berupa pembelajaran, penelitian dan pengabdian memberi kontribusi terhadap kepuasan mahasiswa, demikian pula dalam kaitannya dengan biaya yang dikeluarkan mahasiswa. Hal ini ditunjukkan oleh kerja Zhiltsov (2006) yang mengkaji berbagai model kualitas jasa bahwa variabel-variabel tersebut termasuk perilaku berbelanja, faktor finansial (seperti harga, biaya, atau nilai) menarik untuk dikembangkan dan ditetapkan keterkaitan yang jelas antarvariabel tersebut, kemudian merekomendasikan agar dilakukan eksplorasi berbagai atribut kualitas jasa termasuk independensinya. Karena itu, kesenjangan ini memerlukan pembenahan dalam literatur untuk melayani mahasiswa pada tingkat kepuasannya.

Riportella, Couste, \& Torres (2001) memandang dua peranan mahasiswa dalam proses pendidikannya: 1) mahasiswa sebagai konsumen pendukung jasa dan 2) mahasiswa sebagai mitrapartisipan program akademik yang bertanggungjawab terhadap kegiatan belajarnya sendiri. Karena itu, penelitian ini juga memandang mahasiswa tidak hanya sebagai pelanggan tetapi juga sebagai mitra-partisipan.

Dengan memandang kedudukan mahasiswa sebagai konsumen dan mitra-partisipan pada pendidikan tinggi program sarjana, maka permasalahan penelitian dapat dirumuskan sebagai: 1) Bagaimanakah respon sikap dan persepsi mahasiswa terhadap penyelenggaraan pendidikan pada tataran hasil (outcome level) dari variabel kualitas dan biaya jasa yang dialami serta kepuasan dan loyalitas mahasiswa? 2) Bagaimana model aplikatif anteseden dan konsekuen dari kepuasan mahasiswa yang dapat diungkap berkaitan dengan variabel kualitas \& biaya jasa yang dialami, mitra-partisipan, dan loyalitas mahasiswa? 3) Apakah variabel-variabel pada aspek pelayanan (kualitas jasa pengajaran, penelitian, dan pengabdian pada masyarakat) dan aspek finansial (biaya yang dialami) dapat menyediakan perspektif yang lebih holistik untuk membenahi berbagai kesenjangan dalam literatur manajemen pemasaran secara simultan dalam melayani mahasiswa pada tingkat kepuasannya?

Berdasarkan rumusan masalah tersebut maka tujuan penelitian ini yaitu: 1) untuk mengkaji sikap dan persepsi mahasiswa terhadap penyelenggaraan pendidikan tinggi di Sulawesi Selatan, baik sebagai konsumen maupun sebagai mitra-partisipan pada tataran hasil (outcome) pendidikan tinggi program sarjana terhadap faktor kualitas dan biaya jasa yang dialaminya pada tingkat kepuasan dan loyalitasnya; 2) untuk menverifikasi suatu model aplikatif anteseden dan konsekuen dari kepuasan mahasiswa pada program sarjana dalam hubungannya dengan faktor kualitas dan biaya jasa yang dialami serta loyalitas mahasiswa baik dalam kedudukannya 
sebagai konsumen maupun sebagai mitrapartisipan pada pendidikan tinggi program sarjana; dan 3) untuk menyediakan perspesktif yang lebih holistik dan mengupayakan adanya usulan pembenahan untuk mengisi kesenjangan dalam literatur manajemen pemasaran dalam melayani mahasiswa pada tingkat kepuasannya secara simultan baik dalam kedudukannya sebagai konsumen maupun sebagai mitrapartisipan pada pendidikan tinggi program sarjana.

\section{Kajian Literatur}

\section{Karakteristik Jasa Pendidikan Tinggi}

Jasa pendidikan tinggi adalah salah satu bentuk produk. Jasa didefinisikan setiap tindakan atau perbuatan yang dapat ditawarkan oleh suatu pihak kepada pihak lain yang pada dasarnya bersifat intangible (tidak berwujud fisik) dan tidak menghasilkan kepemilikan sesuatu. (Kotler, 2003). Sekalipun demikian, produk jasa bisa saja berhubungan dengan produk fisik.

Berbagai peneltian dan literatur pemasaran jasa mengungkap bahwa jasa memiliki karakteristik unik yang membedakannya dengan barang. Karakteritik tersebut terdiri dari intangibility, inseparability, variability/ heterogeneity, perishability, dan lack of ownership. Howard Bowen (1981) dalam Buchari (2003:67) menyatakan bahwa universitas sebagai industri jasa yang profesional (professional industries) memiliki karakteristik berikut: "1) These industries are based on an intellectual or esthetic foundation and require of the practioners exceptional skill that can be developed only through long study and experience; 2) Are deeply involved in the advancement of human well being and the cultivation of the civic, cultural, religious, and intellectual life of the nation; and 3) The performance of the services of the professional industries usually requires that practioners be physically in the presence of the clients."

Selanjutnya, dengan karakteristik seperti itu, Bowen (1981) dalam Buchari (2003:68) menekankan bahwa produk perguruan tinggi adalah pembelajaran (instruction), penelitian (research) dan pengabdian masyarakat (public services) dengan produk utama (the chief product) adalah pembelajaran (teaching-learning). Selain dari produk utama tersebut Bowen (1981) dalam Buchari (2003:69) juga mengemukakan produk sampingannya (by-product) berupa personal self discovery, career choice and placement, dan direct satisfactions and enjoyments. Dill (2003) mengemukakan bahwa perguruan tinggi dapat dipandang sebagai bagian dari industrial ekonomi yang menyediakan derajat akademik, penelitian, dan pengabdian.

Verry \& Davies (1976) dalam Schwartz \& Scafidi, (2001) menggambarkan pendidikan tinggi sebagai penyedia jasa untuk output pendidikan sebagai berikut: "i) Instructional or teaching outputs (the transmission of knowledge). This involves the teaching of various kinds (general, vocational etc.), in different subjects and at different levels, all generally leading to certification of some description; ii) Research outputs (the extension of knowledge); (iii) General Social Services. This is something of a catch-all category for the less tangible and often most controversial activities of the university. It is intended to include the general socialization function (the instillation of desirable work habits, co-operative behaviour, respect for laws and institutions, and, some would say, docility and obedience), and the related function, primarily benefiting employers, of sorting, selecting and screening individuals..."

Hal ini sejalan dengan Tri Dharma Perguruan Tinggi berupa pembelajaran, penelitian dan pengabdian masyarakat. Pembelajaran dalam tri darma perguruan tinggi tersebut tercermin dalam kurikulum (termasuk kokurikuler dan ekstrakurikuler) yang akan membekali mahasiswa untuk terjun ke masyarakat, penelitian memberi bekal mencari dan menghasilkan ilmu pengetahuan agar dapat meningkatkan, menyebarkan, menginterpretasikan, dan mengaplikasikan ilmu pengetahuan, serta membudayakan kreativitas ilmiah. Pengabdian masyarakat dapat berupa pemeliharaan lingkungan, kebersihan, konsultan di berbagai bidang dan sebagainya.

Dalam buku pedoman penjaminan mutu pendidikan tinggi, buku VIII yang dikeluarkan oleh DIKTI (2005), dikemukakan bahwa penelitian merupakan kegiatan telaah taat kaidah dalam upaya menemukan kebenaran atau menyelesaikan masalah dalam ilmu pengetahuan, teknologi, atau kesenian (ipteks). Penelitian juga merupakan 
kegiatan dalam upaya menghasilkan pengetahuan empirik, teori, konsep, metode, model, atau informasi baru yang memperkaya ipteks. Selanjutnya, dalam buku IX dikemukakan bahwa program pengabdian kepada masyarakat lebih diarahkan pada pemanfaatan dan penerapan hasil penelitian maupun hasil pendidikan untuk kesejahteraan dan kemajuan masyarakat.

Setiap perguruan tinggi dilengkapi dengan kurikulum pendidikan tinggi yang merupakan seperangkat rencana dan pengaturan mengenai isi maupun bahan kajian dan pelajaran serta cara penyampaian dan penilaiannya yang digunakan sebagai pedoman penyelenggaraan kegiatan belajar-mengajar di perguruan tinggi.

\section{Kualitas Jasa yang dialami (Perceived Service Quality)}

Kualitas jasa yang dialami (perceived service quality) adalah keputusan konsumen tentang adanya kesatuan keunggulan atau superioritas menyeluruh (Parasuraman, Zeithaml, \& Berry, 1988:15). Perolehan jasa yang berkualitas dipandang strategis dan krusial untuk sukses dan survive dalam perekonomian dewasa ini. Bahkan, di sejumlah negara hampir $70 \%$ dari total angkatan kerjanya berkecimpung dalam sektor ini (Carlzon dalam Fandy, 2005: 258). Kualitas jasa pendidikan adalah sikap yang dihasilkan dari persepsi mahasiswa tentang kinerja persekolahan. (Holdford \& Reinders, 2001).

Kualitas produk (baik barang maupun jasa) berkontribusi besar pada kepuasan pelanggan, loyalitas pelanggan, pangsa pasar, dan profitabilitas. Zeithaml dan Bitner (2000) mengemukakan bahwa kualitas jasa berkonstribusi pada laba melalui dua jalur utama, yaitu pemasaran defensif (devensive marketing) dan pemasaran ofensif (offensive marketing). Selain itu, kualitas jasa juga meningkatkan kemampuan organisasi untuk mempertahankan pelanggan yang selanjutnya mempengaruhi profitabilitas melalui faktor efisiensi biaya, peningkatan penjualan, premium harga, dan word of mouth positif. (Fandy, 2005: 258).

Hartline \& Ferrell (1996) mengemukakan bahwa kemunduran apa pun dalam kepuasan konsumen berkaitan dengan kualitas jasa yang rendah dan akan menjadi perhatian pada organisasi, serta bisa menghasilkan konsekuensi yang tidak diinginkan. Selanjutnya, mereka menyimpulkan bahwa, organisasi harus mencari cara efektif mengelola kontak dengan pelanggannya untuk menjamin bahwa sikap dan perilaku karyawan konduktif kearah penyerahan jasa yang bekualitas.

Kualitas yang dialami dibedakan dari kualitas objektif, yang merujuk pada aspek objektif atau corak sesuatu atau kejadian (Holbrook \& Corfman, 1985). Beberapa ahli menyarankan bahwa kualitas sebagai bentuk evaluasi menyeluruh dari suatu produk yang serupa dalam berbagai cara untuk menyikapinya merupakan derajat pertentangan antara persepsi konsumen dan ekspektasinya (Parasuraman, Zeithaml, \& Berry, 1988). Istilah ekspektasi digunakan secara berbeda dalam literatur kualitas jasa dan kepuasan konsumen. Terutama, dalam literatur kepuasan, ekspektasi dipandang sebagai prediksi yang dibuat oleh pelanggan tentang kemungkinan untuk terjadi selama transaksi atau pertukaran di masa datang. Sebaliknya, dalam literatur kualitas jasa, ekspektasi dipandang sebagai kebutuhan dan keinginan pelanggan, yaitu apa yang mereka alami tentang penyediaan jasa yang seharusnya ditawarkan ketimbang yang akan ditawarkan (Parasuraman, Zeithaml, \& Berry, 1988).

\section{Biaya Jasa yang dialami (Perceived Price)}

Harga dan biaya dalam pendidikan dikemukakan oleh Winston (1997) bahwa biaya pendidikan adalah harga yang dibayarkan mahasiswa ditambah subsidi (Price + Subsidy = Costs). Penjelasan yang sama juga dikemukakan oleh Troutt (1998:9) dalam laporannya yang berjudul "Straight Talk About College Costs and Prices" bahwa Costs adalah what institutions spend to provide education and related educational services to students, sedangkan Price adalah what students and their families are charged and what they pay.

Dalam Lee (2005) dikemukakan definisi harga moneter yang dialami (perceived monetary price) bahwa harga moneter yang dialami adalah representasi persepsi atau persepsi subyektif pelanggan tentang harga objektif. Harga objektif adalah suatu harga dasar (raw price), atau harga satuan. Harga obyektif tersebut merupakan harga 
suatu produk atau jasa. Evaluasi mahasiswa terhadap harga objektif adalah pandangannya terhadap harga yang riil dibayarkan, yang biasa disebut harga referensi. (Lee, 2005).

\section{Kepuasan Mahasiswa}

Kepuasan adalah ukuran tipikal sebagai suatu perasaan umum atau sebagai kepuasan dengan transaksi dalam istilah kemampuannya untuk memenuhi kebutuhan dan ekspektasi konsumen (Fornell, dkk. 2006; Zeithaml \& Bitner, 2000). Dalam kajian literatur kepuasan pelanggan yang dilakukan Giese \& Cote (2002) mengidentifikasi bahwa ada 20 definisi yang diacu dalam riset kepuasan pelanggan selama periode waktu 30 tahun.

Penjelasan dominan dalam literatur marketing tentang kepuasan pelanggan adalah diskonfirmasi harapan (Makover, B., 2003: 37). Pada dasarnya, model diskonfirmasi harapan menggambarkan konsumen ketika membentuk harapan mengenai kinerja (kualitas) suatu produk. Menurut model tersebut, ada tiga prediktor kepuasan: harapan ("mungkin atribut atau kinerja produk pada suatu tingkat kinerja yang spesifik"), diskonfirmasi ("hasil perbandingan antara apa yang diharapkan dan apa yang diamati"), dan kinerja ("jumlah produk yang dialami atau outcome atribut jasa yang dialami") (Oliver, 1997: 28). Ketiganya menyatakan tentang diskonfirmasi adalah: diskonfirmasi negatif - kinerja di bawah pagu (yaitu, harapan); diskonfirmasi positif kinerja di atas pagu; dan diskonfirmasi nol kinerja mengkonfirmasikan harapan.

\section{Loyalitas Mahasiswa}

Konseptualisasi loyalitas mahasiswa dikemukakan oleh berbagai pakar seperti Hennig-Thurau, dkk. (2001), Riportella, dkk. (2001), Zuluaga (2003). Konseptualisasi loyalitas mahasiswa oleh Jacoby \& Chestnut (1978) dalam Hennig-Thurau, dkk. (2001) dijelaskan bahwa dengan memparalelkan berkaitan dengan konsep loyalitas konsumen maka loyalitas mahasiswa (student loyalty) memuat suatu komponen sikap dan komponen perilaku, keduanya sangat dekat satu sama lain.

Isu kedua berkaitan dengan istilah mahasiswa (student) dan interpretasinya dalam konteks loyalitas, sebagaimana telah digambar- kan oleh Hennig-Thurau, dkk. (2001) bahwa kelebihan terhadap institusi pendidikan yang memiliki mahasiswa loyal tidak terbatas pada periode ketika konsumen terdaftar secara formal sebagai mahasiswa; loyalitas mahasiswa yang lama juga dapat menjadi penting untuk kesuksesan institusi.

\section{Kerangka Konseptual}

Rantai kualitas-kepuasan-loyalitas diuji dalam beberapa studi. Sebagai contoh, Lee dkk. (2000) mempelajari 521 konsumen dari tiga industri yang berbeda (yaitu, entertainment park, aerobic school, and investment consulting firm). Mereka menguji mediasi aturan kepuasan antara kualitas jasa dan keinginan belanja kembali. Mereka memperoleh bahwa kualitas jasa merupakan anteseden dari kepuasan konsumen dari ketiga sampel tersebut. Mereka menyimpulkan bahwa kualitas jasa yang dialami menghasilkan kepuasan konsumen dan kepuasan konsumen berpengaruh lebih kuat terhadap keinginan belanja kembali ketimbang kualitas jasa.

Anteseden utama yang berkaitan dengan 'nilai' yang dialami telah dimuat oleh beberapa penulis, seperti produk, kualitas jasa dan harga yang dialami (Chang \& Wildt, 1994; Dodds dkk., 1991). Studi lain juga menunjukkan bahwa kualitas jasa, kepuasan, nilai transaksi dan harga yang dialami merupakan anteseden nilai yang dialami. (Duman, 2002: 22).

Selanjutnya, studi ini juga mengintegrasikan model faktor determinan dan faktor pengaruh kepuasan mahasiswa (atau pelanggan) dengan melibatkan variabel loyalitas mahasiswa. Selain itu, faktor mahasiswa sebagai mitra-partisipan dari jasa yang dirasakan. Dill (1995) dan Guolla (1999) dalam Riportella, Couste, \& Torres. (2001), menunjukkan bahwa variabel mahasiswa sebagai mitra-partisipan dari jasa yang dialami memuat derajat dedikasi dan minat sebagai faktor dalam model. Penelitian lain yang berkaitan dengan ini dilakukan oleh Zuluaga (2003) dan menyaebutkan faktor tersebut sebagai variabel mitra-partisipan (user co-production). Variabel ini diukur dengan memandang mahasiswa sebagai partisipan efektif dari pendidikannya sendiri. Indikator yang digunakan adalah mengerjakan pekerjaan rumah dan mengusulkan tugas-tugas dikelas; minat 
untuk belajar giat dan aktif berpartisipasi di kelas (motivasi); sikap pada institusi, perkuliahan dan dosen; upaya untuk terintegrasi dalam budaya dan kehidupan sosial kampus; dan dinilai sebagai jasa publik.

Berbagai penelitian kepuasan mahasiswa melibatkan variabel moderator atau kontrol dalam studinya. Misalnya Antonicic, Scarlat, \& Erzetic (2005) dalam studinya melibatkan variabel jenis pendidikan responden (bergelar, non gelar), umur, jender, panjang pengalaman kerja, tingkat pendidikan, dan industry of the company. Penelitian ini juga melibatkan berbagai varibel moderator yang disebut variabel karakteristik mahasiswa.

Untuk keperluan pengujian secara empiris, hipotesis alternatif yang diperhatikan dalam penelitian ini sebagai berikut: 1) Kualitas pembelajaran berpengaruh positif terhadap pencapaian kepuasan mahasiswa; 2) Kualitas penelitian berpengaruh positif terhadap pencapaian kepuasan mahasiswa; 3) Kualitas pengabdian berpengaruh positif terhadap pencapaian kepuasan mahasiswa; 4) Kualitas pembelajaran berpengaruh positif terhadap biaya jasa yang dialami; 5) Kualitas penelitian berpengaruh positif terhadap biaya jasa yang dialami; 6) Kualitas pengabdian berpengaruh positif terhadap biaya jasa yang dialami; 7) Kualitas pembelajaran berpengaruh positif terhadap terhadap mitra-partisipan; 8) Kualitas penelitian siswa berpengaruh positif terhadap loyalitas mahasiswa.

Hipotesis untuk prediksi (tidak langsung) juga menjadi perhatian dalam penelitian ini.

\section{Metode Penelitian}

\section{Rancangan dan Waktu Penelitian}

Studi ini adalah induktif dan eksplanatori. Studi ini merupakan jenis penelitiaan problem solving. Studi ini juga dapat dipandang sebagai kombinasi dari pendekatan elementer dengan pendekatan interpretive pada penelitian organisasional. (Frisby, 1995 dalam Makover, 2003). Waktu penelitian mulai dari pengembangan isntrumen hingga penulisan dilakukan pada Januari Agustus 2007.

\section{Populasi dan Sampel}

Populasi target penelitian adalah mahasiswa program sarjana di Sulawesi Selatan. Dalam penelitian ini semua mahasiswa program sarjana di semua universitas yang ada di Kota Makassar merupakan populasi sasaran. Sampel dibatasi hanya untuk mahasiswa program sarjana tingkat akhir (sementara mengikuti matakuliah skripsi).

Metode pengambilan sampel yang digunakan adalah Sampel Acak Kelompok Tahap Ganda (Multistage Cluster Random Sampling). Perhitungan ukuran sampel minimal menggunakan metode Cochran (1977) dan dihitung sebagai berikut:

$$
n=\frac{N z_{a / 2}^{2} p(1-p)}{(N-1) d^{2}+z_{a / 2}^{2} p(1-p)}=\frac{17174(1,96)^{2}(0,309)(1-0,309)}{(17174-1) 0,05^{2}+(1,96)^{2}(0,309)(1-0,309)}=322
$$

berpengaruh positif terhadap terhadap mitrapartisipan; 9) Kualitas pengabdian berpengaruh positif terhadap terhadap mitra-partisipan; 10) Partisipasi mahasiswa sebagai mitra-partisipan berpengaruh positif terhadap pencapaian kepuasan mahasiswa; 11) Partisipasi mahasiswa sebagai mitra-partisipan berpengaruh positif terhadap biaya jasa yang dialami; 12) Partisipasi mahasiswa sebagai mitra-partisipan berpengaruh positif terhadap loyalitas mahasiswa; 13) Biaya jasa yang dialami berpengaruh positif terhadap pencapaian kepuasan mahasiswa; 14) Biaya jasa yang dialami berpengaruh positif terhadap loyalitas mahasiswa; dan 15) Kepuasan Maha-
Di mana $n=$ jumlah responden; $N=$ ukuran populasi (dalam tahap ketiga); $p=$ proporsi mahasiswa tingkat akhir (tengah menyusun skripsi); $d=$ deviasi $5 \% ; z_{a / 2}=$ nilai disttribusi- $z$ untuk $\mathrm{a}=5 \%(=1,96)$.

\section{Variabel dan Instrumen Penelitian}

Variabel dalam penelitian ini adalah kualitas produk Pendidikan Tinggi (kualitas pengajaran, penelitian, dan pengabdian), Biaya jasa, kepuasan, loyalitas dan mitra-partisipan. Instrumen penelitian dikembangkan dalam bentuk kuesioner. Uraian variabel dan kuesioner untuk mengukur variabel sebagai berikut: 


\section{Kualitas Produk Pendidikan Tinggi.}

Sebagaimana diketahui, produk pendidikan tinggi dalam pelayanan pada mahasiswa adalah pengajaran, penelitian, dan pengabdian pada masyarakat. Jadi kualitas produk yang dimaksud adalah kualitas pengajaran, kualitas penelitian, dan kualitas pengabdian.

Ada lima unsur yang menentukan kualitas jasa menurut Parasuraman, Zeithaml \& Berry (1988) dalam memodifikasi model Servqual (service quality), yaitu reliability (kehandalan), responsiviness (daya tanggap), assurance (jaminan), empaty (empati), dan tangible (bukti fisik). Karena itu instrumen mengacu pada dimensi tersebut yang disajikan dalam bentuk kuesioner kualitas pengajaran, kualitas penelitian dan kualitas pengabdian.

\section{Biaya jasa yang dialami}

Kusioner untuk mengukur variabel biaya jasa yang dialami diadopsi dari kuesioner yang telah dikembangkan dalam Deloitte-Inra (2005). Dimensi perceived price sebagaimana dalam Deloitte-Inra (2005) adalah affordable, pricing, dan tranparancy. Indikator dikembangkan dalam kuesione berdasarkan dimensi tersebut.

\section{Kepuasan mahasiswa}

Sejumlah studi (seperti Fornell, dkk. 1996, Fandy (2005:365); Chan dkk., 2003, dan Fornell, dkk. 2006) menunjukkan bahwa ada tiga aspek penting yang perlu ditelaah dalam kerangka pengukuran kepuasan pelanggan, yaitu: 1) kepuasan menyeluruh (overall satisfaction); 2) konfirmasi harapan, yakni tingkat kesesuaian antara kinerja yang dirasakan dengan ekspektasi; dan 3) perbandingan dengan situasi ideal, yaitu kinerja produk yang dirasakan dibandingkan dengan produk ideal menurut persepsi konsumen. Jadi, kuesioner kepuasan konsumen diukur berkaitan dengan evaluasi terhadap diri sendiri berupa perasaan konsumen akibat adanya kinerja yang dialami.

\section{Loyalitas mahasiswa}

Kuesioner yang digunakan untuk mengukur loyalitas mahasiswa menggunakan aspek-aspek dasar loyalitas menurut Zeithaml \& Bitner. (2000), yaitu share information, say positive things, recommended friends, continue purchasing, purchase additional service, dan test new service. Selain itu, Antonicic, Scarlat, \& Erzetic (2005) juga meneliti loyalitas mahasiswa pada pendidikan kewirausahaan. Indikator loyalitas yang digunakan adalah: 1) saying positive things; 2 ) recommend to people, who are thinking about education; 3) encourage friends and relatives to engage in this education; 4) consider this education provider as a first choice, dan 5) engage more in education from this provider in the next years.

\section{Mitra-Partisipan (user co-producer)}

Mitra-partisipan dalam penelitian ini adalah peranan mahasiswa terhadap dirinya sendiri baik secara langsung maupun tidak langsung dalam proses pendidikan untuk mencapai keinginan dan harapannya di Perguruan Tinggi. Dimensi variabel mitra-partisipan merupakan faktor-faktor dari dalam diri mahasiswa, yaitu minat (interest), motivasi (motivation), kreativitas (creativity) dan dedikasi (dedication) terhadap jasa layanan pendidikan tinggi.

Butir pernyataan yang digunakan dalam merespon indikator semua variabel di atas adalah tingkat pesetujuan mahasiswa, mulai dari sangat tidak setuju hingga sangat setuju.

\section{Pemeriksaan Sifat-sifat Pengukuran}

Sifat-sifat pengukuran diperiksa melalui analisis faktor konfirmatori (confirmatory factor analysis). Sifat-sifat pengukuran yang dimaksud adalah reliabilitas dan validitas internal. Unidimensional adalah syarat yang diperlukan untuk analisis reliabilitas dan validitas. Validitas yang diperhatikan adalah validitas konvergen dan divergen, sedang reliabilitas yang digunakan adalah Cronbach-alpha, Construct Reliability, dan Average Variance Extracted (AVE)., dimana $\gamma=$ standar loading dan $\varepsilon=$ error. (Hair, dkk. 1998: 612)

Indikator yang memberikan tingkat validitas dan reliabilitas memadai dari konstruk berdasarkan kuesioner penelitian sebagai berikut:

\section{Konstruk Kualitas jasa Pembelajaran}

KJPG5 Ruang kelas secara visual menarik (nyaman dan bersih)

KJPG9 Para dosen menyajikan materi dengan jelas 


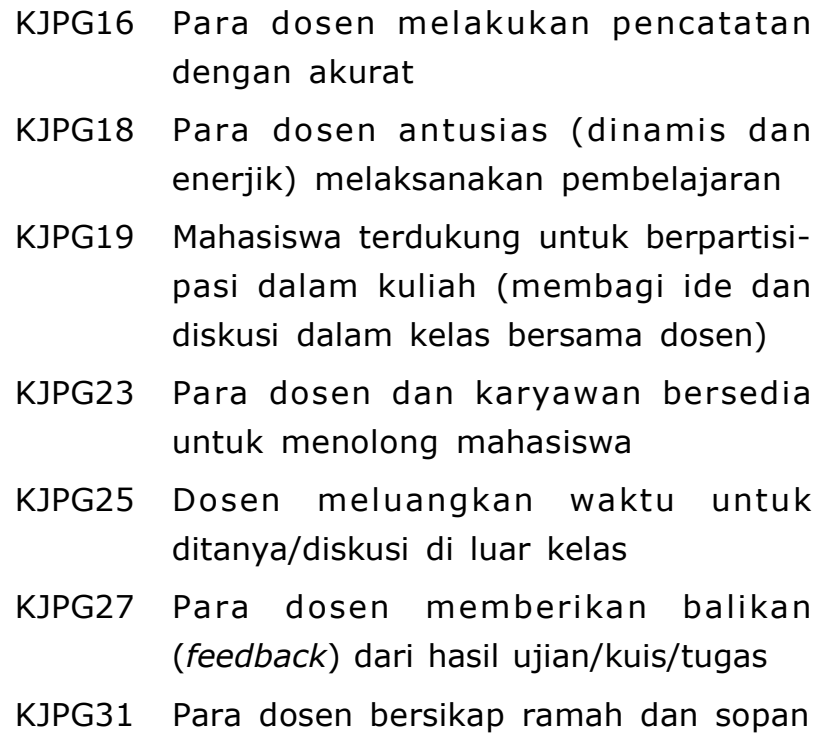

Konstruk KJPN: Kualitas jasa Penelitian

KJPN10 Petunjuk dan dukungan dari dosen dengan metode-metode dan teknikteknik penelitian

KJPN13 Suasana dalam kampus mendukung kerja penelitian mahasiswa

KJPN15 Waktu tunggu penentuan tim penguji skripsi

KJPN18 Kesediaan dosen pembimbing membaca dan merespon kerja penelitian mahasiswa

KJPN20 Kesediaan dosen pembimbing untuk konsultasi

KJPN24 Keyakinan mahasiswa akan kemampuan/ kualifikasi dosen pembimbing dalam kerja penelitiannya

KJPN32 Dosen/karyawan memahami kebutuhan penelitian mahasiswa

\section{Konstruk KJPM: Kualitas jasa Pengabdian} Masyarakat

KJPM1 Ada pedoman kegiatan pengabdian

KJPM4 Petunjuk dari dosen/karyawan mengenai area bidang pekerjaan dalam persiapan kegiatan

KJPM5 Ketepatan pelaksanaan proses pembimbingan kegiatan pengabdian (rencana dan waktu)

KJPM9 Informasi dari dosen/karyawan mengenai topik, area, dan sumber-sumber pendanaan kegiatan
KJPM15 Balikan dari dosen pembimbing terhadap kerja pengabdian

KJPM16 Keyakinan mahasiswa akan kemampuan/kualifikasi dosen pembimbing dalam kegiatan pengabdiannya

KJPM19 Pemahaman dosen/karyawan akan kebutuhan kerja mahasiswa dalam kegiatan pengabdian

\section{Konstruk HJ: Biaya jasa yang Dialami}

HJ1 Kesesuaian biaya dan kemampuan membayar tanpa kesulitan

HJ4 Keterlibatan mahasiswa dalam penetapan pembiayaan

HJ8 Penetapan pembiayaan (unprofitabilitas)

HJ11 Akurasi bukti pembayaran

\section{Konstruk KM: Kepuasan Mahasiswa}

KM1 Kesesuaian kinerja pembelajaran dengan yang diharapkan

KM5 Keseuaian kinerja penelitian dibanding dengan yang ideal

KM6 Keseuaian kinerja pengabdian dibanding dengan yang ideal

KM8 Kesesuaian kinerja secara menyeluruh dibanding dengan yang ideal

KM9 Kepuasan menyeluruh atas kinerja dosen

KM13 Kepuasan menyeluruh atas iklim kampus

\section{Konstruk LY: Loyalitas Mahasiswa}

LY1 Menyebarkan informasi yang baik mengenai program/

LY2 Senantiasa berkata hal positif mengenai program/

LY3 Mengajak orang lain untuk mengikuti program

LY4 Mengikuti program-program hingga selesai

LY11 Senantiasa loyal terhadap institusi

\section{Konstruk UKP: Mitra-Partisipan (user co- producer)}

UKP5 Selalu tertarik untuk meningkatkan kemampuan dalam bidang yang digeluti

UKP8 Pertisipasi aktif dalam kegiatan-kegiatan yang menyangkut bidang keahlian yang digeluti 
UKP11 Tidak cepat menyerah kalau ada masalah

UKP13 Selalu membuat persiapan-persiapan yang matang

UKP19 Menampilkan pekerjaan/tugas-tugas yang inovatif

UKP22 Senantiasa berbuat untuk kesuksesan belajar

$$
\begin{aligned}
& \hat{Y}_{1}=4,195+0,217 X_{1}+0,042 X_{2}+0,145 X_{3} \\
& \hat{Y}_{2}=0,928+0,225 X_{1}+0,106 X_{2}+0,252 X_{3}+0,039 \hat{Y}_{1} \\
& \hat{Y}_{3}=-0,372+0,230 X_{1}+0,187 X_{2}+0,007 X_{3}+0,227 \hat{Y}_{1}+0,42 \hat{Y}_{2} \\
& \hat{Y}_{4}=-0,412+0,242 \hat{Y}_{1}+0,255 \hat{Y}_{2}+0,192 \hat{Y}_{3}
\end{aligned}
$$

dapat diterima karena memenuhi kriteria threshold-nya, yaitu Bollen-Stine bootstrap = $0.074>0.05,1<c^{2} / d f=1.374<2$, RMSEA $=$ $0.035<0.08$, CFI $=0.963>0.90$, dan TLI $=0.956$ $>0.90$. Persamaan structural model final yang diperoleh dan korelasi multipel kuadrat $R^{2}$-nya dapat disajikan sebagai berikut:

\section{Model Pengukuran dan Struktural}

Jalinan fungsional yang ditunjukkan melalui arah panah diperoleh dari proposisi teoritis berdasarkan hasil studi pustaka yang disajikan dalam kerangka konseptual. Untuk keperluan formulasi matematis berdasarkan Struktural Equation Modeling (SEM) yang digunakan sebagai teknik analisis data maka model pengukuran dan struktural dalam penelitian ini selengkapnya disajikan dalam Gambar 1, di mana: $X_{1}, X_{2}$, dan $X_{3}$ berturut-turut adalah kualitas pembelajaran, kualitas penelitian, dan kualitas pengabdian yang dialami; $Y_{1}, Y_{2}, Y_{3}$, dan $Y_{4}$ berturut-turut adalah mitra-partisipan, biaya jasa yang dialami, kepuasan mahasiswa, dan loyalitas mahasiswa.

\section{Hasil Penelitian dan Pembahasan}

\section{Model anteseden \& konsekuen kepuasan mahasiswa}

Pada awalnya dikembangkan model awal berdasarkan hasil Confirmatory Factor Analysis masing-masing konstruk, namun model tersebut kurang fit dalam menjelaskan sikap dan perilaku mahasiswa terhadap penyelenggaraan pendidikan. Peningkatan model fit dilakukan dengan menggunakan metode building-trimming sehingga nilai chi-kuadrat (dan alternatifnya Bollen-Stine Bootstrap) serta indikes global lainnya dapat memberikan indeks overall model fit yang lebih baik.

Hasil analisis tahap akhir (model final) terhadap model memberikan overall model fit yang di mana

$X_{1}, X_{2}$, dan $X_{3}$ berturut-turut adalah kualitas pembelajaran, penelitian, dan pengabdian yang dialami.

$Y_{1}, Y_{2}, Y_{3}, Y_{4}$ berturut-turut adalah mitrapartisipan; biaya jasa yang dialami; kepuasan mahasiswa; dan loyalitas mahasiswa.

Model final yang diperoleh melalui persamaan struktural ini diharapkan dapat menjelasakan perilaku dan sikap mahasiswa dalam pendidikan tinggi tingkat sarjana.

\section{Pengujian hipotesis}

Hasil estimasi parameter (regression weight) disajikan dalam Tabel 1. Dalam tabel tersebut nampak bahwa semua parameter model memberikan pengaruh yang positif dan hanya 3 parameter pengaruh yang tidak signifikan pada taraf 0.05 , baik melalui metode Maksimum Likelihood maupun Bootstrap. Ketiga parameter tersebut adalah pengaruh kualitas penelitian terhadap mitra-partisipan, mitra-partisipan terhadap biaya yang dialami, dan kualitas pengabdian terhadap kepuasan mahasiswa.

\section{Pengaruh Variabel Intervening (Mediator)}

Berdasarkan model final pengaruh tidak langsung masing-masing variabel eksogen terhadap variabel endogen, maka variabel intervening sebagai mediator dapat memperkuat atau memperlemah pengaruh langsung masing-masing 


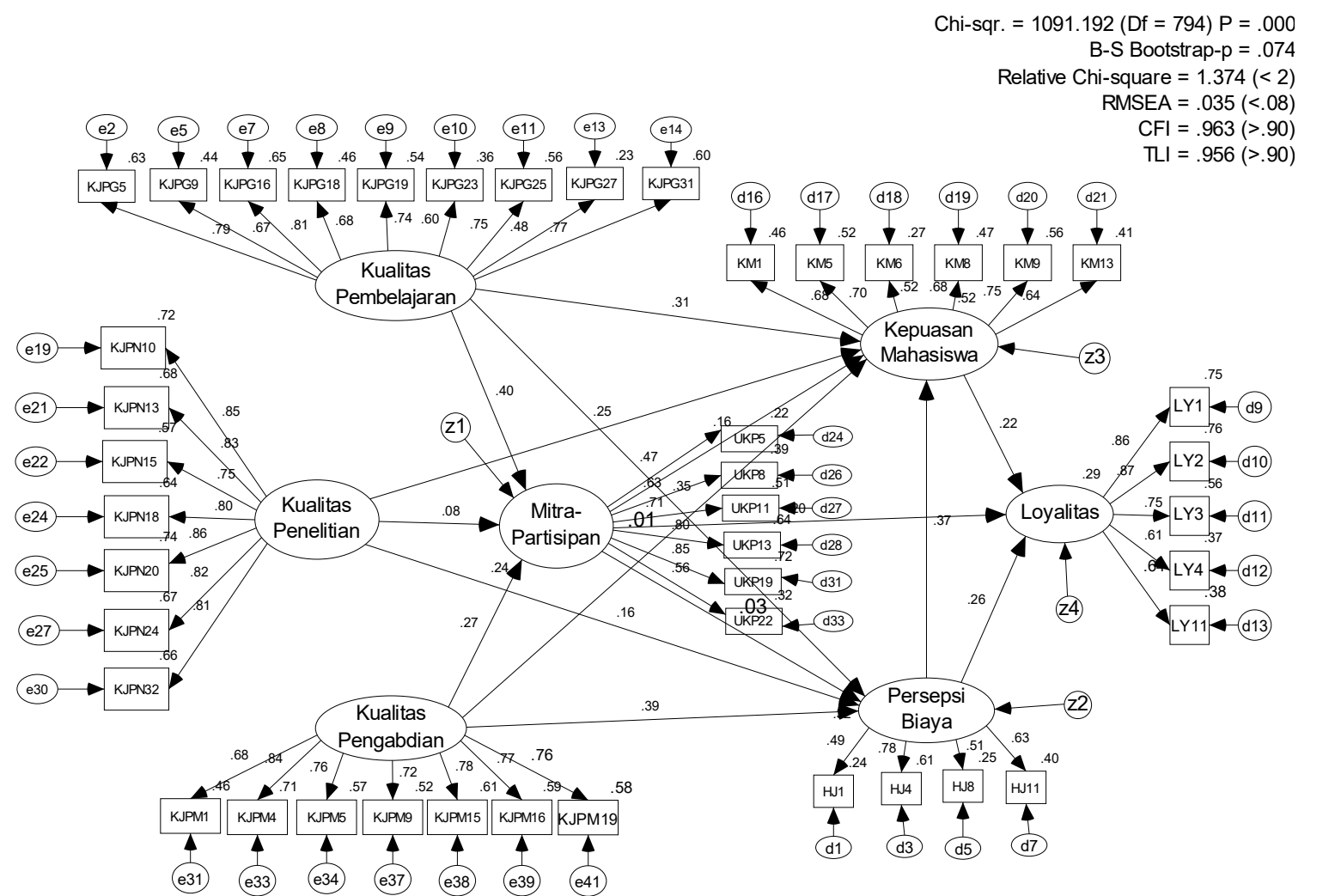

Model B (Tahap FINAL)

Standardized estimates

\section{Gambar 1. Model Aplikatif Anteseden dan Konsekuen Kepuasan Mahasiswa}

variabel eksogen. Hasil analisis melalui untuk efek mediating variabel intervening dari model (tahap akhir) disajikan dalam Tabel 2.

\section{Pembahasan Hasil Penelitian}

\section{Signifikansi Model}

Model yang diperoleh melalui persamaan struktural diharapkan dapat menjelasakan persepsi dan sikap mahasiswa dalam pendidikan tinggi tingkat sarjana. Model tersebut dinyatakan dapat diterima karena overall model fit sudah memenuhi sebagian besar thresholdnya. Hal ini sejalan dengan teori yang telah dikemukakan sebelumnya bahwa penyampaian jasa yang berkualitas tinggi akan menghasilkan kepuasan dan loyalitas pelanggan. (Fandy, 2005). Karena itu, model anteseden dan konsekuen yang diperoleh dalam penelitian ini dapat mejadi model aplikatif terhadap pendidikan tinggi dalam mengantisipasi persaingan pasar global.

Pengaruh kualitas jasa pembelajaran, kualitas jasa penelitian, dan kualitas jasa pengabdian masyarakat terhadap mitra-partisipan.
Hasil analisis menunjukkan bahwa konstruk kualitas jasa pembelajaran mempunyai pengaruh positif yang signifikan terhadap mitra-partisipan. Demikian pula dengan kualitas jasa pengabdian memiliki pengaruh positif yang signifikan terhadap mitra-partisipan. Namun, kualitas jasa penelitian memiliki pengaruh positif tetapi tidak signifikan terhadap mitra-partisipan pada taraf signifikansi 0.05 . Sekitar $24 \%$ variasi total konstruk mitrapartisipan ditentukan oleh kualitas jasa pembelajaran, penelitian dan pengabdian secara bersama-sama.

Hasil ini menunjukkan bahwa makin bermutu pelayanan pembelajaran dan pengabdian yang diberikan kepada mahasiswa, maka mahasiswa makin giat dan memberi kontribusi yang tinggi untuk mereka sukses dalam pendidikannya. Kualitas jasa penelitian menurut persepsi mahasiswa memberikan pengaruh positif yang tidak signifikan terhadap peranannya sebagai mitra-partisipan, berarti pelayanan penelitian yang diberikan kepada mahasiswa dari lembaga universitas belum banyak menentukan bagaimana mereka berperan dalam kesuksesan belajarnya sendiri. 
Tabel 1. Estimasi Koefisien Regresi Persamaan Struktural (Tahap Akhir)

\begin{tabular}{|c|c|c|c|c|c|c|c|}
\hline \multicolumn{2}{|l|}{ Regression Weight } & & \multirow[b]{2}{*}{$\begin{array}{l}\text { Unstand. } \\
\text { Estimate }\end{array}$} & \multirow[b]{2}{*}{$\begin{array}{r}\text { Stand. } \\
\text { Estimate }\end{array}$} & \multirow[b]{2}{*}{ S.E. } & \multirow[b]{2}{*}{ T-value } & \multirow[b]{2}{*}{$\mathrm{P}$} \\
\hline & & & & & & & \\
\hline Mitra-Partisipan & $<---$ & Kualitas_Pengabdi & 0.145 & 0.268 & 0.033 & 4.355 & 0.000 \\
\hline Mitra-Partisipan & $<--$ & Kualitas_Pembelaj & 0.217 & 0.401 & 0.037 & 5.931 & 0.000 \\
\hline Mitra-Partisipan & $<---$ & Kualitas_Penelitian & 0.042 & 0.078 & 0.030 & 1.388 & 0.165 \\
\hline Persepsi_Biaya & $<---$ & Kualitas_Pembelaj & 0.225 & 0.349 & 0.050 & 4.549 & 0.000 \\
\hline Persepsi_Biaya & $<---$ & Kualitas_Pengabdi & 0.252 & 0.390 & 0.049 & 5.117 & 0.000 \\
\hline Persepsi_Biaya & $<--$ & Mitra-Partisipan & 0.039 & 0.033 & 0.085 & .462 & 0.644 \\
\hline Persepsi_Biaya & $<---$ & Kualitas_Penelitian & 0.106 & 0.164 & 0.039 & 2.699 & 0.007 \\
\hline Kepuasan_Mahasi & $<---$ & Kualitas_Pembelaj & .230 & 0.308 & 0.050 & 4.596 & 0.000 \\
\hline Kepuasan_Mahasi & $<---$ & Mitra-Partisipan & 0.227 & 0.165 & 0.087 & 2.614 & 0.009 \\
\hline Kepuasan_Mahasi & $<---$ & Persepsi_Biaya & 0.420 & 0.365 & 0.099 & 4.266 & 0.000 \\
\hline Kepuasan_Mahasi & $<---$ & Kualitas_Pengabdi & 0.007 & 0.009 & 0.046 & .147 & 0.883 \\
\hline Kepuasan_Mahasi & $<---$ & Kualitas_Penelitian & 0.187 & 0.251 & 0.040 & 4.628 & 0.000 \\
\hline Loyalitas & $<---$ & Kepuasan_Mahasi & 0.192 & 0.222 & 0.070 & 2.728 & 0.006 \\
\hline Loyalitas & $<---$ & Persepsi_Biaya & 0.255 & 0.257 & 0.081 & 3.163 & 0.002 \\
\hline \multirow[t]{3}{*}{ Loyalitas } & $<---$ & Mitra- Partisipan & 0.242 & 0.203 & 0.080 & 3.024 & 0.002 \\
\hline & & & \multicolumn{2}{|c|}{ Bootstrap } & \multicolumn{3}{|c|}{ BC Confidence } \\
\hline & & & SE & Mean & Lower & Upper & $\mathrm{P}$ \\
\hline Mitra-Partisipan & $<---$ & Kualitas_Pengabdi & 0.051 & 0.140 & 0.051 & 0.241 & 0.005 \\
\hline Mitra-Partisipan & $<---$ & Kualitas_Pembelaj & 0.045 & 0.216 & 0.136 & 0.310 & 0.003 \\
\hline Mitra-Partisipan & $<---$ & Kualitas_Penelitian & 0.048 & 0.042 & -0.052 & 0.139 & 0.415 \\
\hline Persepsi_Biaya & $<---$ & Kualitas_Pembelaj & 0.064 & 0.225 & 0.111 & 0.380 & 0.003 \\
\hline Persepsi_Biaya & $<---$ & Kualitas_Pengabdi & 0.063 & 0.252 & 0.136 & 0.390 & 0.003 \\
\hline Persepsi_Biaya & $<---$ & Mitra-Partisipan & 0.105 & 0.048 & -0.170 & 0.231 & 0.820 \\
\hline Persepsi_Biaya & $<--$ & Kualitas_Penelitian & 0.061 & 0.104 & 0.001 & 0.243 & 0.045 \\
\hline Kepuasan_Mahasi & $<---$ & Kualitas_Pembelaj & 0.071 & 0.224 & 0.078 & 0.369 & 0.006 \\
\hline Kepuasan_Mahasi & $<---$ & Mitra-Partisipan & 0.091 & 0.228 & 0.048 & 0.397 & 0.012 \\
\hline Kepuasan_Mahasi & $<---$ & Persepsi_Biaya & 0.127 & 0.440 & 0.234 & 0.735 & 0.004 \\
\hline Kepuasan_Mahasi & $<---$ & Kualitas_Pengabdi & 0.072 & -0.002 & -0.151 & 0.138 & 0.895 \\
\hline Kepuasan_Mahasi & $<---$ & Kualitas_Penelitian & 0.055 & 0.185 & 0.084 & 0.302 & 0.003 \\
\hline Loyalitas & $<---$ & Kepuasan_Mahasi & 0.081 & 0.175 & 0.048 & 0.356 & 0.017 \\
\hline Loyalitas & $<--$ & Persepsi_Biaya & 0.102 & 0.273 & 0.090 & 0.453 & 0.014 \\
\hline Loyalitas & $<---$ & Mitra-Partisipan & 0.095 & 0.250 & 0.072 & 0.452 & 0.011 \\
\hline
\end{tabular}

Sumber: hasil pengolahan data dengan AMOS

Penelitian yang mengaitkan kualitas jasa khususnya yang menyangkut konstruk kualitas jasa dalam penelitian ini dikaitkan dengan peranan mahasiswa sebagai mitra-partisipan belum banyak disajikan dalam publikasi ilmiah. Namun penelitian ini telah menunjukkan bahwa kualitas jasa yang tinggi akan meningkatkan peranan mahasiswa tersebut untuk sukses dalam studinya yang direfleksikan melalui minat, motivasi, dedikasi dan kreativitas mahasiswa dalam proses pendidikannya.

Pengaruh kualitas jasa pembelajaran, kualitas jasa penelitian, kualitas jasa pengabdian masyarakat, dan mitra-partisipan terhadap biaya jasa yang dialami.
Hasil analisis menunjukkan bahwa kualitas jasa pembelajaran mempunyai pengaruh positif yang signifikan terhadap biaya jasa (yang dialami). Kualitas jasa penelitian juga memiliki pengaruh positif yang signifikan terhadap biaya jasa yang dialami. Demikian pula dengan kualitas jasa pengabdian masyarakat berpengaruh positif dan signifikan terhadap biaya jasa yang dialami. Mitrapartisipan memiliki pengaruh langsung yang tidak signifikan terhadap biaya jasa yang dialami pada taraf signifikasi 0.05 .

Ini berarti bahwa makin berkualitas pelayanan pembelajaran dan penelitian yang diberikan kepada mahasiswa maka pendapat mereka berdasarkan hasil penilaiannya mengenai biaya 
Tabel 2. Pengaruh Tidak Langsung dan Total antar Variabel Laten

\begin{tabular}{|c|c|c|c|c|c|c|c|}
\hline & $\begin{array}{l}\text { Kualitas_- } \\
\text { Penelitian }\end{array}$ & $\begin{array}{l}\text { Kualitas_- } \\
\text { Pembelajar }\end{array}$ & $\begin{array}{l}\text { Kualitas_P } \\
\text { engabdian }\end{array}$ & $\begin{array}{c}\text { Mitra- } \\
\text { Partisipan }\end{array}$ & $\begin{array}{c}\text { Persepsi__ } \\
\text { Biaya }\end{array}$ & $\begin{array}{l}\text { Kepuasan_- } \\
\text { Mahasiswa }\end{array}$ & Loyalitas \\
\hline \multicolumn{8}{|c|}{\begin{tabular}{|l|l|l|} 
Indirect Effects - Estimates & & \\
\end{tabular}} \\
\hline \begin{tabular}{|l|} 
Mitra- \\
Partisipan \\
\end{tabular} & 0 & 0 & 0 & 0 & 0 & 0 & 0 \\
\hline $\begin{array}{l}\text { Persepsi_- } \\
\text { Biaya }\end{array}$ & 0.002 & 0.008 & 0.006 & 0 & 0 & 0 & 0 \\
\hline Kepuasan & 0.055 & 0.148 & 0.141 & 0.016 & 0 & 0 & 0 \\
\hline Loyalitas & 0.084 & 0.184 & 0.129 & 0.057 & 0.081 & 0 & 0 \\
\hline \multicolumn{8}{|c|}{ Indirect Effects - Bootstrap Two Tailed Significance (BC) } \\
\hline \multicolumn{8}{|c|}{\begin{tabular}{|l|l|l|l|l|} 
Mitra- & $\ldots$ & $\ldots$ & $\ldots$ \\
Partisipan & $\ldots$ & $\ldots$ & $\ldots$ \\
\end{tabular}} \\
\hline $\begin{array}{l}\text { Persepsi_- } \\
\text { Biaya }\end{array}$ & 0.493 & 0.766 & 0.717 & $\cdots$ & $\cdots$ & $\ldots$ & $\cdots$ \\
\hline Kepuasan & 0.020 & 0.003 & 0.003 & 0.758 & $\ldots$ & $\ldots$ & $\ldots$ \\
\hline Loyalitas & 0.007 & 0.003 & 0.004 & 0.128 & 0.01 & $\ldots$ & $\ldots$ \\
\hline \multicolumn{8}{|c|}{ Total Effects - Estimates } \\
\hline $\begin{array}{l}\text { Mitra- } \\
\text { Partisipan }\end{array}$ & 0.042 & 0.217 & 0.145 & 0 & 0 & 0 & 0 \\
\hline \begin{tabular}{|l} 
Persepsi_- \\
Biaya
\end{tabular} & 0.107 & 0.234 & 0.258 & 0.039 & 0 & 0 & 0 \\
\hline Kepuasan & 0.241 & 0.377 & 0.148 & 0.244 & 0.420 & 0 & 0 \\
\hline Loyalitas & 0.084 & 0.184 & 0.129 & 0.299 & 0.335 & 0.192 & 0 \\
\hline \multicolumn{8}{|c|}{ Total Effects - Bootstrap Two Tailed Significance (BC) } \\
\hline \begin{tabular}{|l|} 
Mitra- \\
Partisipan
\end{tabular} & 0.415 & 0.003 & 0.005 & .. & $\cdots$ & $\cdots$ & $\cdots$ \\
\hline $\begin{array}{l}\text { Persepsi_- } \\
\text { Biaya }\end{array}$ & 0.046 & 0.003 & 0.004 & 0.820 & $\cdots$ & $\cdots$ & $\cdots$ \\
\hline Kepuasan & 0.002 & 0.004 & 0.032 & 0.011 & 0.004 & $\ldots$ & $\ldots$ \\
\hline Loyalitas & 0.007 & 0.003 & 0.004 & 0.004 & 0.004 & 0.017 & $\ldots$ \\
\hline
\end{tabular}

Sumber: hasil pengolahan data dengan AMOS

jasa dari pelayanan yang diberikan akan semakin baik. Hal ini mendukung hasil penelitian Dimkpah, Eseno, \& Akpom (2004) bahwa atribut kualitas yang ditampilkan pendidikan tinggi merupakan penentu penting dari biaya pendidikan. Studi ini juga melihat kualitas jasa pengabdian masyarakat, nampak bahwa makin berkualitas pelayanan pengabdian yang diberikan kepada mahasiswa akan makin baik pendapatnya terhadap biaya jasa yang dibebankan kepadanya.

Selanjutnya, hasil analisis menunjukkan bahwa sekitar 32\% total variasi biaya jasa yang dialami dapat ditentukan oleh kualitas jasa pembelajaran, penelitian, pengabdian, dan mitrapartisipan secara bersama-sama tanpa memperhitungkan pengaruh variabel lainnya.

Penelitian mengenai biaya jasa yang dialami pada pendidikan tinggi belum banyak ditemukan dalam publikasi ilmiah. Pada bidang non pendidikan, Deloitte (2005) mengemukakan bahwa kualitas jasa berpengaruh positif secara langsung terhadap baiaya jasa yang dialami. Demikian pula penelitian yang dilakukan oleh Loughlin \& Coenders (2002) bahwa kualitas jasa berpengaruh langsung terhadap value (perceived level of product quality relative to the price paid aspects of the customer experience), diperkuat pula oleh penelitian Zhao, dkk. (2002) bahwa kualitas jasa secara langsung berpengaruh pada nilai yang dialami (customer's evaluation of expected price given a quality and quality given a price).

Ini berarti bahwa dengan pelayanan yang berkualitas tinggi maka persepsi mahasiswa mengenai biaya pendidikan yang dikeluarkannya akan semakin baik, yang berarti pula bahwa evaluasi mahasiswa atas biaya pendidikan yang direfleksikan oleh affordabilitas, penetapan biaya, dan transparansi pengelolaan anggaran semakin baik bila mereka memperoleh layanan tridarma PT yang berkualitas tinggi. Hal ini sejalan dengan 
pendapat Idochi (2004:170) bahwa kalau jasa pendidikan tinggi berkualitas tinggi, maka akan menuntut ketepatan penggunaan dan pemakaian biaya yang tinggi pula.

Oleh karena itu, informasi ini dapat menjadi acuan dalam rangka pengembangan penjaminan mutu pendidikan pada butir pengelolaan keuangan, bahwa dengan layanan yang bermutu tinggi akan berdampak pada pengelolaan keuangan pendidikan yang baik, sehingga penggunaan anggaran pendidikan dari masyarakat dapat terealisasi dengan baik pula dan akibatnya hasil (outcome) kegiatan yang dibiayai semakin bermutu.

Pengaruh kualitas jasa pembelajaran, kualitas jasa penelitian, kualitas jasa pengabdian masyarakat, mitra-partisipan, dan biaya jasa yang dialami terhadap kepuasan mahasiswa.

Hasil analisis menunjukkan bahwa kualitas jasa pembelajaran mempunyai pengaruh positif yang signifikan terhadap kepuasan mahasiswa. Kualitas jasa penelitian juga memiliki pengaruh positif yang signifikan terhadap kepuasan mahasiswa. Mitra-partisipan juga memiliki pengaruh positif yang signifikan terhadap kepuasan mahasiswa. Demikian pula dengan biaya jasa yang dialami memiliki pengaruh positif yang signifikan terhadap kepuasan mahasiswa. Kualitas jasa pengabdian masyarakat memiliki pengaruh positif tetapi tidak signifikan terhadap kepuasan mahasiswa pada taraf signifikansi 0.05.

Hasil ini tidak berbeda jauh dengan temuan Riportella, dkk. (2001) dalam penelitiannya terhadap mahasiswa program MBA bahwa kualitas jasa pembelajaran berpengaruh positif yang signifikan terhadap kepuasan mahasiswa. Dalam penelitian ini tidak hanya kualitas jasa pembelajaran yang diperhatikan, tetapi juga kualitas jasa penelitian dan pengabdian yang juga berpengaruh positif dan signifikan terhadap kepuasan mahasiswa. Lebih lanjut Riportella dkk. melaporkan bahwa mitra-partisipan (dedikasi) juga berpengruh positif dan signifikan secara langsung terhadap kepuasan dan loyalitas mahasiswa. Demikian pula dengan penelitian Zuluaga (2003) terhadap mahasiswa di Universitat de Barcelona dengan menggunakan SEM bahwa kualitas jasa yang dialami berpengaruh positif secara langsung terhadap kepuasan mahasiswa dan mitra-partisipan berpengaruh positif dan signifikan terhadap kepuasan mahasiswa. Sementara itu, penelitian Mavondo, dkk (2004) juga menggunakan SEM, menunjukkan bahwa kualitas jasa pembelajaran berpengaruh positif terhadap kepuasan untuk mahasiswa internasional, tetapi pengaruhnya tidak signifikan untuk mahasiswa lokal. Hasil ini juga sejalan dengan hasil penelitian Holdford \& Patkar (2003) pada mahasiswa pendidikan farmasi bahwa atribut/ dimensi kualitas jasa pendidikan secara signifikan berpengaruh positif terhadap kepuasan mahasiswa.

Hasil pengujian hipotesis untuk pengaruh tidak langsung menunjukkan bahwa secara signifikan kualitas jasa pembelajaran memiliki pengaruh tidak langsung terhadap kepuasan mahasiswa melalui mitra-partisipan pada taraf 0,05 . Biaya jasa yang dialami memediasi pengaruh kualitas jasa pembelajaran terhadap kepuasan mahasiswa secara signifikan pada taraf 0,05. Secara bersama-sama, hasil pengujian hipotesis juga menunjukkan bahwa mitra-partisipan dan biaya jasa yang dialami secara signifikan memediasi pengaruh kualitas jasa pembelajaran terhadap kepuasan mahasiswa pada taraf signifikansi 0,05. Dengan demikian, mitrapartisipan dan biaya jasa yang dialami secara signifikan memperkuat pengaruh kualitas jasa pembelajaran terhadap kepuasan mahasiswa baik secara sendiri-sendiri maupun secara bersama-sama pada taraf 0,05.

Selanjutnya, hasil pengujian hipotesis menunjukkan bahwa pengaruh tidak langsung kualitas jasa penelitian terhadap kepuasan mahasiswa melalui mitra-partisipan memberikan pengaruh positif tetapi tidak signifikan. Secara bersama-sama mitra-partisipan dan biaya jasa yang dialami memediasi kualitas jasa penelitian terhadap kepuasan mahasiswa. Dengan demikian, mitra-partisipan dan biaya jasa yang dialami memperkuat pengaruh kualitas jasa penelitian terhadap kepuasan mahasiswa secara bersamasama, secara sendiri, mitra-partisipan tidak signifikan dalam memperkuat pengaruh kualitas jasa penelitian terhadap kepuasan tetapi haga yang dialami memperkuat pengaruh tersebut pada taraf signifikansi 0,05. 
Hasil pengujian hipotesis menunjukkan bahwa secara signifikan kualitas jasa pengabdian memiliki pengaruh tidak langsung yang positif terhadap kepuasan mahasiswa melalui mitrapartisipan. Melalui biaya jasa juga signifikan pada taraf 0.05. Akibatnya, hasil pengujian tersebut menunjukkan bahwa, secara bersama-sama, pengaruh tidak langsung kualitas jasa pengabdian terhadap kepuasan mahasiswa melalui mitrapartisipan dan biaya jasa juga signifikan pada taraf 0.05. Karena pengaruh langsung kualitas jasa pengabdian terhadap kepuasan mahasiswa tidak signifikan pada taraf 0,05, maka mitrapartisipan dan biaya jasa yang dialami merupakan mediator lengkap (complete mediator) untuk pengaruh kualitas jasa pengabdian terhadap kepuasan mahasiswa baik secara sendiri-sendiri maupun secara bersama-sama. Pengaruh tidak langsung mitra-partisipan terhadap kepuasan melalui biaya jasa yang dialami adalah positif tetapi tidak signifikan pada taraf 0,05 . Jadi biaya jasa yang dialami kurang kuat dalam memberikan pengaruh mitra-partisipan terhadap kepuasan mahasiswa.

Selanjutnya, hasil analisis menunjukkan pula bahwa sekitar $52 \%$ variasi total kepuasan mahasiswa ditentukan oleh kualitas jasa pembelajaran, kualitas jasa penelitian, kualitas jasa pengabdian, mitra-partisipan, dan biaya jasa yang dialami secara bersama-sama.

Pengaruh mitra-partisipan, biaya jasa yang dialami, dan kepuasan mahasiswa terhadap loyalitas mahasiswa.

Hasil analisis menunjukkan bahwa mitrapartisipan mempunyai pengaruh positif yang signifikan terhadap loyalitas mahasiswa. Biaya jasa yang dialami juga memiliki pengaruh positif yang signifikan terhadap loyalitas mahasiswa. Demikian pula dengan kepuasan mahasiswa memiliki pengaruh positif yang signifikan terhadap loyalitas. Hasil ini sejalan dengan penelitian Riportella dkk (2001) terhadap mahasiswa program MBA, bahwa mitra-partisipan berpengaruh positif terhadap kepuasan mahasiswa, dan kepuasan mahasiwa berpengaruh positif terhadap intensitas untuk mengikuti kuliah pada mata kuliah lainnya (loyalitas). Demikian pula dengan penelitian Helgensen \& Nesset (2007) terhadap mahasiswa program sarjana muda di
Norwegia dengan menggunakan SEM bahwa kepuasan mahasiswa berpengaruh positif terhadap loyalitas mahasiswa dan kinerja institusi pendidikan.

Hasil pengujian hipotesis juga menunjukkan bahwa pengaruh tidak langsung kualitas jasa pembelajaran terhadap loyalitas melalui mitrapartisipan adalah signifikan dan melalui biaya jasa yang dialami juga signifikan pada taraf 0.05 . Melalui kepuasan juga signifikan pada taraf 0.05 . Jadi mitra-partisipan, biaya jasa yang dialami, dan kepuasan adalah mediator lengkap yang signifikan pada pengaruh tidak langsung kualitas jasa pembelajaran terhadap loyalitas secara sendiri-sendiri. Hasil pengujian hipotesis juga menunjukkan bahwa pengaruh tidak langsung kualitas jasa pembelajaran melalui mitrapartisipan, biaya jasa yang dialami, dan kepuasan secara bersama-sama terhadap loyalitas adalah signifikan pada taraf 0.05 . Karena kualitas jasa pembelajaran tidak signifikan pengaruh langsungnya terhadap loyalitas, maka total pengaruhnya sama dengan pengaruh tidak langsungnya. Dengan demikian mitra-partisipan, biaya jasa yang dialami, dan kepuasan merupakan mediator lengkap dan memperkuat pengaruh kualitas jasa pembelajaran terhadap loyalitas baik secara sendiri-sendiri maupun secara bersamasama.

Hasil-hasil ini sejalan dengan penelitian Riportella, dkk. (2001) bahwa kepuasan mahasiswa dapat memperkuat pengaruh kualitas jasa jasa pembelajaran terhadap intensitas mengikuti kuliah pada mata kuliah lainnya (loyalitas).

Pengaruh tidak langsung kualitas jasa penelitian terhadap loyalitas melalui mitrapartisipan adalah positf tetapi tidak signifikan, melalui biaya jasa yang dialami dan kepuasan adalah signifikan pada taraf 0.05 . Hasil pengujian hipotesis menunjukkan pula bahwa pengaruh tidak langsung kualitas jasa penelitian melalui mitra-partisipan, biaya jasa yang dialami, dan kepuasan secara bersama-sama terhadap loyalitas adalah signifikan pada taraf 0.05. Karena kualitas jasa penelitian tidak signifikan pengaruh langsungnya terhadap loyalitas, maka total pengaruhnya sama dengan pengaruh tidak langsungnya. Dengan demikian mitra-partisipan, 
biaya jasa yang dialami, dan kepuasan merupakan mediator lengkap dan memperkuat pengaruh kualitas jasa penelitian terhadap loyalitas secara bersama-sama, secara sendiri, hanya mediator mitra-partisipan yang tidak signifikan dalam memperkuat pengaruh kualitas jasa penelitian terhadap loyalitas.

Pengaruh tidak langsung kualitas jasa pengabdian terhadap loyalitas melalui mitrapartisipan biaya jasa yang dialami secara sendirisendiri juga signifikan, tetapi melalui kepuasan tidak signifikan. Dengan demikian, mitra-partisipan dan biaya jasa yang dialami secara sendiri-sendiri adalah mediator lengkap yang signifikan pada pengaruh kualitas jasa pengabdian terhadap loyalitas. Hasil pengujian hipotesis menunjukkan bahwa pengaruh tidak langsung kualitas jasa pengabdian melalui mitra-partisipan, biaya jasa yang dialami, dan kepuasan secara bersama-sama terhadap loyalitas adalah signifikan pada taraf 0.05. Karena kualitas jasa pengabdian tidak signifikan pengaruh langsungmya terhadap loyalitas, maka total pengaruhnya sama dengan pengaruh tidak langsungnya. Dengan demikian mitra-partisipan, biaya jasa yang dialami, dan kepuasan merupakan mediator lengkap dan memperkuat pengaruh kualitas jasa pengabdian terhadap loyalitas secara bersama-sama, secara sendiri, hanya mediator kepuasan mahasiswa yang tidak signifikan dalam memperkuat pengaruh kualitas jasa pengabdian terhadap loyalitas.

Pengaruh tidak langsung mitra-partisipan terhadap loyalitas melalui biaya jasa yang dialami tidak signifikan tetapi melalui kepuasan adalah signifikan pada taraf 0.05. Dengan demikian biaya jasa yang dialami dan kepuasan secara bersamasama tidak signifikan dalam memperkuat pengaruh mitra-partisipan terhadap loyalitas, tetapi secara sendiri hanya kepuasan yang memperkuat pengaruh mitra-partisipan terhadap loyalitas pada taraf signifikansi 0,05 . Pengaruh tidak langsung biaya jasa yang dialami melalui kepuasan terhadap loyalitas adalah signifikan pada taraf 0.05. Jadi kepuasan memperkuat pengaruh biaya jasa yang dialami terhadap loyalitas pada taraf signifikansi 0,05.

Selanjutnya, hasil analisis menunjukkan pula bahwa sekitar $29 \%$ variasi total loyalitas mahasiswa ditentukan oleh mitra-partisipan, biaya jasa yang dialami, dan kepuasan secara bersamasama tanpa memperhitungkan pengaruh variabel lainnya dalam model.

Total variasi dari kepuasan dan loyalitas mahasiwa yang diperoleh tersebut diatas tidak terlalu jauh berbeda dengan hasil penelitian Zuluaga (2003) yang memperoleh sekitar 69\% total variasi kepuasan mahasiswa ditentukan oleh kualitas jasa, service outcome, dan mitrapartisipan, demikian pula dengan Riportella, dkk (2001) yang memperoleh sekitar $46 \%$ total variasi loyalitas (intensi mengkuti kuliah professor) ditentukan oleh kepuasan mahasiswa, kualitas jasa pembelajaran dan mitra-partisipan (minat dan dedikasi).

\section{Simpulan dan Saran}

\section{Simpulan}

Dari hasil analisis dan pembahasan yang telah dilakukan, maka dapat ditarik beberapa simpulan sebagai berikut. Persepsi dan Sikap mahasiswa terhadap penyelenggaraan pendidikan tinggi di Sulawesi Selatan menunjukkan bahwa kualitas jasa pembelajaran, penelitian, dan pengabdian pada masyarakat berdasarkan hasil analisis deskriptif tergolong dalam kategori sedang. Penilaian mahasiswa terhadap pengeloalaan pembiayaan pendidikan yang diberlakukan universitas juga tergolong dalam kategori sedang. Demikian pula dengan tingkat kepuasan dan loyalitas mahasiswa, masih tergolong dalam kategori sedang. Variabel mitra-partisipan, yaitu peranan mahasiswa itu sendiri dalam berpartisipasi di perguruan tingginya tergolong tinggi. Melalui model anteseden dan konsekuen kepuasan mahasiswa yang telah diverifikasi, diperoleh bahwa semua parameter model memberikan pengauh yang positif, hanya tiga parameter model yang tidak signifikan pada taraf signifikasi 5\%. Ini berarti bahwa secara umum, hasil verifikasi model dapat diterima sebagai model aplikatif anteseden dan konsekuen kepuasan mahasiswa pada tingkat sarjana di Sulawesi Selatan. Dalam kedudukan mahasiswa sebagai konsumen maupun sebagai mitrapartisipan, maka diperoleh bahwa mitra-partisipan dan biaya jasa yang dialami secara signifikan memperkuat pengaruh kualitas jasa pembelajaran terhadap kepuasan mahasiswa baik secara 
sendiri-sendiri maupun secara bersama-sama. Mitra-partisipan, biaya jasa yang dialami, dan kepuasan mahasiswa merupakan mediator lengkap dalam memperkuat pengaruh kualitas jasa pembelajaran terhadap loyalitas baik secara sendiri-sendiri maupun secara bersama-sama. Mitra-partisipan dan biaya jasa yang dialami memperkuat pengaruh kualitas jasa penelitian terhadap kepuasan mahasiswa secara bersamasama, secara sendiri, mitra-partisipan tidak signifikan dalam memperkuat pengaruh kualitas jasa penelitian terhadap kepuasan tetapi biaya jasa yang dialami memperkuat pengaruh tersebut secara signifikan. Mitra-partisipan, biaya jasa yang dialami, dan kepuasan merupakan mediator lengkap dalam memperkuat pengaruh kualitas jasa penelitian terhadap loyalitas secara bersamasama, secara sendiri, hanya mediator mitrapartisipan yang tidak signifikan dalam memperkuat pengaruh kualitas jasa penelitian terhadap loyalitas. Mitra-partisipan dan biaya jasa yang dialami merupakan mediator lengkap (complete mediator) dalam memperkuat pengaruh kualitas jasa pengabdian terhadap kepuasan mahasiswa baik secara sendiri-sendiri maupun secara bersama-sama. Tetapi biaya jasa yang dialami tidak signifikan dalam memperkuat pengaruh mitra-partisipan terhadap kepuasan mahasiswa. Mitra-partisipan, biaya jasa yang dialami, dan kepuasan merupakan mediator lengkap dan memperkuat pengaruh kualitas jasa pengabdian terhadap loyalitas secara bersama-sama, secara sendiri, hanya mediator kepuasan mahasiswa yang tidak signifikan dalam memperkuat pengaruh kualitas jasa pengabdian terhadap loyalitas. Biaya jasa yang dialami dan kepuasan secara bersamasama tidak signifikan dalam memperkuat pengaruh mitra-partisipan terhadap loyalitas, tetapi secara sendiri hanya kepuasan yang memperkuat pengaruh mitra-partisipan terhadap loyalitas. Sementara itu, kepuasan mahasiswa memperkuat pengaruh biaya jasa yang dialami terhadap loyalitas mahasiswa. Oleh karena itu, perspesktif yang lebih holistik untuk mengisi kesenjangan dalam literatur manajemen pemasaran dalam melayani mahasiswa pada tingkat kepuasannya secara simultan baik pada pendidikan tinggi program sarjana dapat dinyatakan bahwa makin berkualitas layanan jasa yang diberikan kepada mahasiswa menurut persepsi dan keterlibatannya akan semakin puas dan loyal mahasiswa tersebut dalam penyelenggaraan pendidikan; atau ekuivalen bahwa makin positif sikap dan perilaku mahasiswa terhadap penyelenggaraan pendidikan, akan semakin puas dan loyal mahasiswa tersebut, dan tentu saja berakibat akan semakin baik kinerja pendidikan tinggi ke depan dalam perspektif jangka panjang.

\section{Saran}

Berdasarkan pada hasil analisis dan pembahasan yang telah dilakukan dapat dinyatakan bahwa keterkaitan antara penyelenggara jasa khususnya dosen merupakan salah satu determinan yang penting dari persepsi mahasiswa tentang kualitas jasa. Sebagai hasilnya, pimpinan universitas (manajer pendidikan) harus mencari cara untuk merekrut, memperlakukan, dan mempertahankan para dosen potensial untuk mendukung struktur organisasi. Dosen harus ditingkatkan kompetensinya sehingga berakibat pada peningkatan kualitas jasa yang mereka sediakan bagi mahasiswanya. Selain itu, top manajer dapat dengan segera melakukan pembenahan internal organisasi utamanya dalam perbaikan penyelenggaraan pendidikan sehingga dapat meningkatkan dan mempertahankan perolehan nilai akreditasi dari pemerintah. Perbaikan penyelenggaraan pendidikan dapat dimulai dari kurikulum yang sesuai dengan harapan-harapan konsumen mahasiswa melalui jasa yang ditawarkan kepadanya berupa jasa pembelajaran, jasa penelitian dan jasa pengabdian masyarakat sebagaimana ditunjukkan dalam penelitian ini. Setelah itu, barulah melakukan pembenahan terhadap berbagai layanan pendukung jasa utama tersebut dalam kegiatan ekstra kurikuler yang dapat menjamin tiga ranah kognitif, afektif dan psikomotorik mahasiswa sehingga skill yang diperlukan untuk hidup dan terjun kemasyarakat telah dimiliki dengan baik oleh mahasiswa. Peranan mahasiswa untuk sukses dalam proses pendidikannya juga tidak dapat diabaikan, sebagaimana ditunjukkan dalam penelitian ini, sehingga disarankan pula agar dalam melakukan pembenahan internal organisasi dan pengembangan kurikulum senantiasa dapat memberikan dan menumbuhkan minat, motivasi, dedikasi, dan kreativitas mahasiswa. 


\section{Pustaka Acuan}

Antonicic, B. Scarlat, C., \& Erzetic, B.H. 2005. The Quality of Entrepreneurship Education and the Intention to Continue Education: Slovenia and Romania. Managing Global Transitions 3 (2):197212

Buchari Alma. 2003. Pemasaran Stratejik Jasa Pendidikan. Alfabeta: Bandung.

Chan, L.K., Hui, Y. V., Lo, H.P., Tse, S.K., Tso, G.K.F., \& Wu, M.L. 2003. Consumer satisfaction index: new practice and findings. European Journal of Marketing 37 (5/6): 872-909.

Chang, T. Z., \& Wildt, A. R. 1994. Price, product information, and purchase intention: An empirical study. Journal of the Academy of Marketing Science, 22(1), 16-27.

Cochran, WG., 1977. Sampling Techniques. 3rd. Edition. Wiley a Sons. NY

Deloitte. 2005. Development of indicators on consumer satisfaction and Pilot survey. Final Report. The European Commission, Directorate General on Health and Consumer Protection.

Direktorat Jenderal Pendidikan Tinggi. 2005. Pedoman Penjaminan Mutu Pendidikan Tinggi, Buku I s.d X. Depdiknas: Jakarta

Dill, D. 1995. Through Deming's Eyes: A Cross-National Analysis of Quality Assurance in Higher Education. Quality in Higher Education, 1, 95 - 110.

Dill, D. 2003. Allowing the market to rule: the case of the United States. The University of North Carolina: Chapel Hill.

Dimkpah, Y.O., Eseonu, M.O., \& Akpom, U.N. 2004. The Impact of College Quality on Tuition: A Hedonic Analysis. Journal for Economic Educators 4 (2). Winter.

Duman, T. 2002. A Model of Perceived Value for Leisure Travel Products. Disertasi. The Pennsylvania State University

Fandy T. \& Gregorius C. 2005. Service Quality \& Satisfaction. Andi: Yogyakarta.

Fandy T. 2005. Pemasaran Jasa. Bayumedia Publishing. Malang

Forbes, L. \& Linda, J. 2004. Building an International Student Market: Educational-Balanced Scorecard Solutions for Regional Australian Cities. International Education Journal 5 (4): 502-520.

Fornell, C., Mithas, S., Morgeson III, F. V., \& Krishnan, M. S. 2006, Customer Satisfaction and Stock Prices: High Returns, Low Risk. Journal of Marketing, 70 (January), 3-14.

Fornell, C., Johnson, M.D., Anderson, E.W., Cha, J., \& Bryant, B.E. 1996. The American Customer Satisfaction Index: Nature, purpose and findings. Journal of Marketing 60, 7-18

Giese, J. L. \& Cote, J. A. 2002. Defining Consumer Satisfaction. Academy of Marketing Science Review, 2000(1): $1-24$

Guolla, M. 1999. Assessing the teaching quality to student satisfaction relationship: Applied customer satisfaction research in the classroom. Journal of Marketing Theory and Practice, 7 (3): 87 - 98.

Hair, F.J., Anderson, R.E, Tatham, R.L., \& Balck, W.C. 1998. Multivariate Data Analysis. $7^{\text {th }}$ edition. Prentice Hall: New Jersey.

Helgensen, W. \& Nesset, E. 2007. What accounts for student's loyalty? Some field study evidence. International Journal of Educational Management. Vol. 21 (2): 126-143.

Hennig-Thurau, T., Langer, M. F. \& Hansen, U. 2001. Modelling and Managing Student Loyality: An approach based on the concept of relationship quality. Journal of Service Research. 3(4): 331344.

Holbrook, M. and Corfman, K. 1985. Quality and value in the consumption experience: Phaedrus rides again. In J.Jacoby and J. Olson (Eds.) Perceived Quality. Lexington, MA: Lexington Books, 31-51

Holdford, D., \& Patkar, A. 2003. Identification of the Service Quality Dimentions of Pharmaceutical Education. American Journal of Pharmaceutical Education, 67 (4): Article 108 
Holdford, D., \& Reinders, T. P. 2001. Development of an Instrument to Assess Student Perceptions of the Quality of Pharmaceutical Education. American Journal of Pharmaceutical Education 65: 125131

Idochi Anwar, M. 2004. Administrasi Pendidikan dan Manajemen Biaya Pendidikan: Teori, konsep dan isu. Alfabeta: Bandung.

Jacoby, J. \& R. W. Chestnut. 1978. Brand Loyalty: Measurement and Management. New York: Wiley.

Kotler, P., 2003. Marketing Management: An Asian Perspective. New Jersey: Prentice Hall, Inc.

Lee, S. Y. 2005. A Conceptual Model of The Roles of Price, Quality, and Intermediary Constructs in Determining Behavioral Intention to Visit A Festival. Dissertation. Texas A\&M University.

Loughlin, C. \& Coenders, G. 2002. Application of europian cutomer satiesfaction index to postal services. SEM vs PLS. Online http://www3.udg.edu/fcee/economia/n4.pdf Diakes 14/12/2006.

Makover, B. 2003. Examining the Employee-Customer Chain in the Fitness Industry. Dissertation. The Florida State University.

Mavondo, F.T., Tsarenko, Y., \& Gabbott, M. 2004. International and Local Student Satisfaction: Resources and Capabilities Perspective. Journal of Marketing for Higher Education, 14 (1): 4160.

Oliver, R. L. 1997. Satisfaction: A behavioral perspective on the consumer. New York: McGraw-Hill.

Parasuraman, A., ZeithamI V.A, \& Berry, L.L., 1988. SERVQUAL: A Multiple Item Scale for Measuring Customer Perceptions of Service Quality, Journal of Retailing, vol 64.

Riportella, C.C., Couste, N.L. \& Torres, P.R. 2001. Measurement and Effects of Teaching Quality: An Empirical Model Applied to Masters Program. Business Economics Series 10: 01-31.

Schwartz, A.E., \& Scafidi, B.P. 2001. Quality Adjusted Price Indices for Four Year Colleges. The Bureau of Labor Statistics: Brookings

Troutt, W. E. 1998. Straight Talk About College Costs and Prices. Report of The National Commission on the Cost of Higher Education.

Undang-Undang Nomor 20 Tahun 2003 Tentang Sistem Pendidikan Nasional.

Winston, G. C. 1997. College Costs: Subsidies, Intuition, and Policy. The National Commission on the Cost of Higher Education. Boston.

Zeithaml, V.A., \& Bitner, M.J. 2000. Service Marketing. Boston: Irwin McGraw Hill.

Zhao, P., Hu, S., Fornell, C., \& Liu, J. 2002. Building a New National Customer Satisfaction Index: the Research on Chinese Customer Satisfaction Index. China Business Research Center.

Zhiltsov, M. 2006. Service Quality Models. Helsinki University of Technology.

Zuluaga, L.C.D. 2003. Public Services User Satisfaction: An Application to Higher Education. Center for Research in Welfare Economy. University of Barcelona. 